\title{
Implementing the Problem-Based Learning in Order to Improve the Students' HOTS and Characters
}

\author{
J. Jailani $^{1}{ }^{*}$, S. Sugiman ${ }^{1}$, Ezi Apino ${ }^{1}$ \\ Department of Mathematics Education, Graduate School of Universitas Negeri Yogyakarta. \\ Jalan Colombo No. 1, Karangmalang, 55281, Yogyakarta, Indonesia \\ * Corresponding Author. Email: jailani@uny.ac.id \\ Received: 31 December 2017; Accepted: 31 December 2017
}

\begin{abstract}
Abstrak
The study was to describe the implementation of Problem-Based Learning (PBL) toward the improvement of students' Higher Order Thinking Skill (HOTS) and characters and to describe the obstacles that had been encountered within the implementation. The study was a mixed research that made use of concurrent mixed method design. The population in the study was the students from eight junior high schools that had been selected from six provinces in Indonesia namely the Yogyakarta Special Region, Bengkulu, South Borneo, West Nusa Tenggara, Southeast Sulawesi and Papua. There were 648 students who had been selected randomly from these schools. The researchers conducted the PBL process within the experimental classes and the expository learning process within the eight control classes. The data gathering process was conducted through the test, the self-assessment and the open questionnaire. The quantitative data analysis was conducted inferentially using multivariate and univariate analysis, while the qualitative data analysis was conducted descriptively. The results of the study showed that: (1) the implementation of PBL had been more effective in comparison to the expository one in terms improving the students' HOTS; (2) the implementation of PBL had not been more effective in comparison to the expository one in terms of improving the students' characters; and (3) in overall the obstacles that had been encountered within the implementation of PBL process were related to the teachers' unpreparedness, the time allocation, the unequal students' input, the students' learning habits and the difficult assessment.
\end{abstract}

Keywords: problem-based learning, HOTS, characters

How to Cite: Jailani, J., Sugiman, S., \& Apino, E. (2017). Implementing the problem-based learning in order to improve the students' HOTS and characters. Jurnal Riset Pendidikan Matematika, 4(2), 247-259. doi:http://dx.doi.org/10.21831/jrpm.v4i2.17674

Permalink/DOI: http://dx.doi.org/10.21831/jrpm.v4i2.17674

\section{INTRODUCTION}

Education has an important role in preparing the human resources to encounter multiple challenges in the future. Multiple skills and capacities should be possessed by an individual in relation to the increasingly complex life demands in this $21^{\text {st }}$ Century. One of the important capacities that should be possessed by each individual is the critical thinking capacity (Douglas, 2012; King et al., 2015; Partnership for $21^{\text {st }}$ Century Learning, 2015; Richland \& Simms, 2015). The critical thinking capacity has been one of the indicators in the higher order thinking skills or also known as the HOTS (King, Goodson \& Rohani, 2010; Conklin, 2012; Tan \& Halili, 2015).
The higher order thinking skills or HOTS has been one of forms in the higher and more complex thinking activities (King et al., 2010), which is related to the mathematical insight, the assumption drawing, the analogy and generalization drawing, the logical reasoning, the problem solving and the mathematical communication and connection establishing (Sumarmo \& Nishitani, 2010). The HOTS associate the students to applying and linking the knowledge that they will learn and the knowledge that they have learned. In relation to the cognitive dimension, the HOTS is characterized by the three higher level in the Bloom's taxonomy namely analysis, evaluation and creation (Anderson \& Krathwohl, 2001; Moore 


\title{
Jurnal Riset Pendidikan Matematika, 4 (2), 2017 - 248
}

\author{
J. Jailani, S. Sugiman, Ezi Apino
}

\& Stanley, 2010; Ramos, Dolipas \& Villamor, 2013).

Several facts show that the Indonesian students' HOTS still belong to the low category (Susanti, Kusumah, Sabandar \& Darhim, 2014). One of the indications for this situation might be found in the results of a study by the Trends in International Mathematics and Science Study (TIMSS) that performs assessment toward the students' mathematical and scientific capacity. In the domain of mathematics, the assessment is conducted toward the content and the cognitive dimension. The content dimension includes number, algebra, geometry, data and probability, while the cognitive dimension includes knowledge, implementation and reasoning (Mullis \& Martin, 2012). The results of the study by TIMSS in 1999-2011 show that the Indonesian students' capacity has been low (Mullis et al. 2000, 2004, 2012). In further analysis, the test items that have been administered in the study by TIMSS do not only measure the concept understanding but also the other skills such as analysis, mathematical reasoning and problem solving. These skills refer to the higher order thinking skills or HOTS (Brookhart, 2010). Based on the situation, the researcher might conclude that the educational process within schools should not pursue the orientation toward the material understanding but also the orientation toward other skills and one of the skills which orientation should be pursued is the students' HOTS.

One of the efforts that the government has been pursuing in order to improve the educational quality in Indonesia is reforming the curriculum by means of 2013 Curriculum implementation. The 2013 Curriculum is the continuation of Competence Based Curriculum that was implemented in 2004 and the Educational Unit Level Curriculum that was implemented in 2006; both curriculums have been oriented to the aspects of integrated attitude, knowledge and skills. In the aspect of knowledge, in addition to pursuing the students' understanding toward the materials that will be taught, the 2013 Curriculum have also been oriented to the other competencies such as the thinking and creative acting competencies, the productive competencies and the critical competencies (Mendikbud, 2016a). It is apparent that the 2013 Curriculum facilitates the students' thinking skills development starting from the lower order thinking until the higher order thinking.
In addition to having been oriented toward the HOTS, the 2013 Curriculum has also prioritized the balance between the competencies in the students' cognitive domain and the ones in the students' affective domain. The balance is manifested by developing the character values that will be integrated into the learning activities. In the character education, there are three interrelated and important components namely moral knowing, moral feeling and moral action (Lickona, 1991). This statement shows that the character establishment should be initialized by the knowledge and the understanding toward the morale and then these moral values should be sensed, be contemplated and be applied in actions. Within the educational concept, this process is integrated to the learning process in the classroom. Several characters that might be integrated into the learning process are responsibility, care, cooperation, independence, persistence, hard-work and self-confidence (Mendikbud, 2016b). In order to achieve this learning objective, there should be a learning model that might facilitate the students' HOTS and characters development. One of the learning models that might be recommended, in relation to the development, is the Problem-Based Learning (PBL) model (Weissinger, 2004; Marsigit, 2013).

The PBL has been one of the learning models that might facilitate the students' HOTS (Guedri, 2001; Arends \& Kilcher, 2010). The PBL that has been characterized by the fact that problems become the starting point in the learning process becomes the means for training the students' capacity in understanding the problems (Hmelo-Silver, 2004; Sungur \& Tekkaya, 2006). Furthermore, the problems in the PBL that involve multiple knowledge might train all of the students' capacities in relation to the context that will be used and the students' problem-solving capacity (Loyens, Magda \& Rikers, 2008). The problems that have been implemented in the learning process are designed in order to direct the students to perform a meaningful learning process and to train their critical thinking skills (Bidokht \& Assareh, 2011).

The syntaxes of PBL-based learning process (Arends, 2012) are namely: (1) orienting the students toward the problems; (2) organizing the students to learn; (3) guiding the students to perform investigation both individually and collectively; (4) developing and presenting the problem-solving procedures; and (5) analyzing 


\section{Jurnal Riset Pendidikan Matematika, 4 (2), 2017 - 249}

J. Jailani, S. Sugiman, Ezi Apino

and evaluating the problem-solving process. The syntaxes in the PBL-based learning process might facilitate the students to train their critical thinking capacity (Hmelo-Silver, 2004; Sungur \& Tekkaya, 2006), to improve their in-depth understanding and to improve their capacity in applying the concepts that they have learned (Wirkala \& Kuhn, 2011). The investigative activities, which have been one of the PBL characteristics (Barrows \& Tamblyn in SavinBaden \& Major, 2004) and which are related to the explorative activities, the determination on the focus of the problem, the development of problem-solving activities and the evaluation and reflection, might direct the students to reaccess the knowledge that they have learned. This situation will turn the students' capacity into being more significant and more easily accessed by them when they need to solve problems with different contexts (Wirkala \& Kuhn, 2011).

In relation to the learning orientation of PBL model, the students' characters also become another main objective within the learning activities in addition to their HOTS. The statement is in line with the opinion of Hale \& City (Moss \& Brookhart, 2009), who state that several developmental results that have been attained based on the learning objectives are namely independence and responsibility. This matter is heavily related to the activities of group collaboration in the PBL, which direct the students be responsible toward the tasks of each group. In addition, the teachers do not serve as the main source of knowledge anymore; instead, they direct the students to learn independently both in exploring the problems and in exploring the learning sources that will be used (Bidokht \& Assareh, 2011). Several results from other studies show that PBL has been effective in improving students' responsibility (Araz \& Sungur, 2007), students' independency (English \& Kitsantas, 2013; Loyens, Magda \& Rikers, 2008), students' cooperation (Sunger \& Tekkaya, 2006) and students' tolerance (Fitrianawati \& Hartono, 2016).

Multiple obstacles might appear within the implementation of PBL model. These obstacles appear because the students are not accustomed to the implementation of this learning model; as a result, they have difficulties in understanding the learning materials through the PBL activities (Bouhujis, 2011). These difficulties are the ones in generalizing the ideas and the ones in understanding the direction of the given tasks (Mei Heong et al., 2012). Furthermore, several students who have high individualism often have difficulties in cooperating with their peers. This situation has caused those students to be passive because they are not interested and are not motivated to attend the learning process well (Chan, 2012).

The obstacles within the implementation of PBL model are also perceived by the teachers. Several teachers sense that the time for preparing and implementing the PBL process has been lack. In line with the statement, the teachers sense that there should be more than one teacher in a classroom in order that the role of a facilitator might be carried out well (Wirkala \& Kuhn, 2011). Not only in serving as a facilitator, the teachers also encounter obstacles in performing the assessment toward the students' understand-ing during the learning process (Chan, 2012).

Based on the theoretical reviews and the previous studies, the researcher assumes that the PBL model might effectively improve the students' HOTS and characters. In 2016 the researcher had developed and HOTS-oriented problem-based learning sets and these learning sets have been validated by both the experts and the teachers. These learning sets are expected to contribute to the development of the students' HOTS and characters. Thereby, the objective of this study is to describe the PBL implementation in order to improve the students' HOTS and characters and to describe the obstacles that have been encountered within the implementation.

\section{METHOD}

The study was a mixed researcher that made use of concurrent mixed method design. The population in the study was the students from eight junior high schools that had been spread in six provinces of Indonesia namely the Province of Yogyakarta Special Region, the Province of Bengkulu, the Province of Southern Borneo, the Province of West Nusa Tenggara, the Province of Southeast Celebes and the Province of Papua. From this population, the researcher selected randomly 648 students as the sample in the study. The selected sample divided into two groups namely the experimental group that consisted of 355 students and the control group that consisted of 293 students. The experimental group provided with the problembased learning treatment, while the control group provided with the direct (expository) 
learning treatment. The details of the sample in the study were provided in the Table 1 .

The data gathering was conducted through the test, the self-assessment and the open questionnaire. The test was conducted in order to identify the students' HOTS after the learning process had been conducted. Then, the self-assessment was performed in order to identify the students' character development which included persistence, responsibility, hardwork, cooperateon, care, tolerance and selfconfidence. The test and the self-assessment administered toward all students who had been selected as the sample, both in the experimental group and in the control group. Next, the open questionnaire was completed by the teachers and would be used in identifying the obstacles that the teachers encountered within the implementation of PBL model.

The data analysis consisted of the inferential analysis and the descriptive analysis. The inferential analysis was conducted in multivariate (MANOVA) and univariate (posthoc) manner with the significance rate $\alpha=5 \%$. MANOVA was used in order to test whether there had been differences in the average score of students' HOTS and character development between the experimental class and the control class or not. If the results of multivariate analysis had been significant, then the researcher conduct the univariate (post-hoc) analysis in order to investigate which treatment (PBL or expository) had been more effective in improving the students' HOTS and characters. On the other hand, in performing the descriptive analysis the researcher made use of formulation on the obstacles that the teachers encountered within the implementation of IBL. The procedures in conducting this qualitative data analysis referred to steps proposed by Cresswell (2013) namely: organizing the data; reading and composing memo; describing, classifying and translating the data into the codes and the themes; interpreting the data; and presenting and visualizing the data. After performing these steps, the researcher performed an overall interpretation in order to identify the teachers' obstacles within the PBL implementation.

\section{RESULTS AND DISCUSSION}

\section{Result}

Data Analysis on the Students' HOTS and Characters

The data that had been attained from the results of the study were analyzed under the multivariate (MANOVA) manner and the univariate (post-hoc) manner by means of SPSS. The multivariate analysis was conducted in order to identify whether there had been significant differences between the mean score of the students' HOTS and that of the students' characters in the PBL (experimental) class and the expository (control) class. The assumption that should be proven prior to performing the multivariate analysis was that the data had multivariate normal distribution and homogenous covariance matrix. The multivariate normal distribution might be identified by creating scatter plot that contained the pairs of mahalanobis distance point $\left(d_{j}^{2}\right)$ and $x_{p}^{2}\left(\left(n-j+\frac{1}{2}\right) / n\right)$ or $q_{i}$ and by determining its correlation coefficient value (Johnson \& Wichern, 2007). The scatter plot and its correlation coefficient $(r)$ for the experimental group and for the control group might be viewed in Figure 1.

Table 1. The Details on the Number of the Sample

\begin{tabular}{|c|c|c|c|}
\hline \multirow{2}{*}{ Province } & \multirow{2}{*}{ School } & \multicolumn{2}{|c|}{ Number of Sample } \\
\hline & & Experimental & Control \\
\hline \multirow{2}{*}{ Yogyakarta Special Region } & Negeri 3 Banguntapan Senior High School & 27 & 26 \\
\hline & Negeri 4 Gamping Senior High School & 32 & 30 \\
\hline \multirow{2}{*}{ Bengkulu } & Negeri 16 Kota Bengkulu Senior High School & 52 & 25 \\
\hline & MTs Assalakum Bengkulu & 19 & 15 \\
\hline South Borneo & An-Nahl Senior High School & 60 & 63 \\
\hline West Nusa Tenggara & Negeri 3 Batukliang Utara Senior High School & 50 & 24 \\
\hline Southeast Celebes & Negeri 2 Baubau Senior High School & 50 & 49 \\
\hline \multirow[t]{2}{*}{ Papua } & Negeri 3 Biak Senior High School & 65 & 61 \\
\hline & $\begin{array}{r}\text { Total } \\
\text { Total Sample }\end{array}$ & $\begin{array}{ll}355 & \\
& 648 \\
\end{array}$ & 293 \\
\hline
\end{tabular}


Jurnal Riset Pendidikan Matematika, 4 (2), 2017 - 251

J. Jailani, S. Sugiman, Ezi Apino

. PBL Group

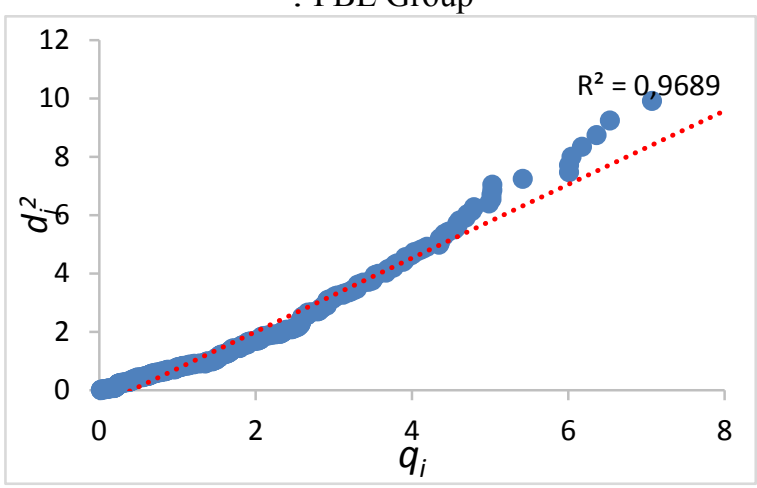

Expository Group

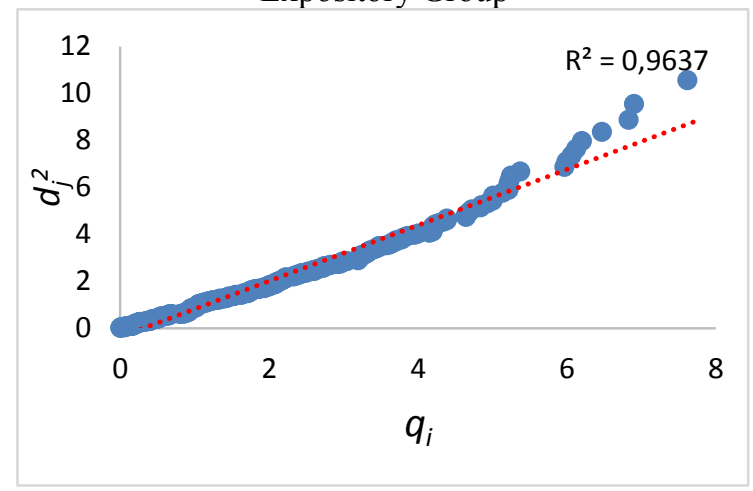

Figure 1. The Scatter Plot for the PBL and Expository Group

Figure 1 showed that the data distribution for the PBL group had been inclined to form a straight line and the correlation $(r)$ between the mahalanobis distance $\left(d_{j}^{2}\right)$ and $q_{i}$ had been equal to 0.984 . Thereby, the assumption of multivariate normal distribution for the PBL classroom had been proven. On the other hand, the data distribution for the expository class had also been inclined to form a straight line and the correlation $(r)$ between the mahalanobis distance $\left(d_{j}^{2}\right)$ and $q_{i}$ had been 0.982 . This statement implied that the assumption of multivariate normal distribution in the expository class had also been proven.

Table 2. Box's M Test of Equality of Covariance Matrixes

\begin{tabular}{lrr}
\hline Box's M & & 2.601 \\
F & & .864 \\
df1 & & 3 \\
df2 & & 435634516.909 \\
Sig. & & .459 \\
\hline \multicolumn{2}{c}{ The assumption of } & similarity in the
\end{tabular}
covariance matrix between the two groups (PBL and expository) might be identified through the Box's $M$ test. The results of Box's M test that had been conducted toward the data in the study provided in Table 2.
Based on Table 2, it was apparent that the Box's M test score that had been attained had been equal to 2.601 with significance rate value that had been equal to 0.459 . Thereby, the researcher might conclude that the covariance matrix of both groups had been homogenous; as a result, the assumption on the covariance matrix had been met.

After both assumptions had been met, the researcher performed the multivariate (MANOVA) test. The MANOVA test was conducted in order to investigate whether there had been differences between the students' HOTS and the students' characters in the PBL class and the expository class. The results of multivariate test by presented in Table 3 below.

Based on the results that had been displayed in Table 3 above, the $\mathrm{F}$ test had been equal to 21.088 and the significance rate that had been equal to 0.00 . In the significance rate $=$ $5 \%$, the researcher might conclude that there had been differences between the mean score of the students' HOTS and of the students' characters in the PBL class and the expository class. After completing the analysis in this stage, the researcher performed then univariate (post-hoc) test in order to identify which treatment had been more effective in improving the students' HOTS and students' characters.

Table 3. The Multivariate Test

\begin{tabular}{llrrrrc}
\hline Effect & & Value & \multicolumn{1}{c}{ F } & Hypothesis df & Error df & Sig. \\
\hline Intercept & Pillai's Trace & .939 & $4999.894^{\mathrm{b}}$ & 2.000 & 645.000 & .000 \\
& Wilks' Lambda & .061 & $4999.894^{\mathrm{b}}$ & 2.000 & 645.000 & .000 \\
& Hotelling's Trace & 15.504 & $4999.894^{\mathrm{b}}$ & 2.000 & 645.000 & .000 \\
& Roy's Largest Root & 15.504 & $4999.894^{\mathrm{b}}$ & 2.000 & 645.000 & .000 \\
\hline Group & Pillai's Trace & .061 & $21.088^{\mathrm{b}}$ & 2.000 & 645.000 & .000 \\
& Wilks' Lambda & .939 & $21.088^{\mathrm{b}}$ & 2.000 & 645.000 & .000 \\
& Hotelling's Trace & .065 & $21.088^{\mathrm{b}}$ & 2.000 & 645.000 & .000 \\
& Roy's Largest Root & .065 & $21.088^{\mathrm{b}}$ & 2.000 & 645.000 & .000 \\
\hline
\end{tabular}


The univariate test was conducted by means of independent sample t-test. The hypotheses that the researcher tested were as follows: (1) the PBL model had been more effective in terms of improving the students' HOTS than the expository learning model; and (2) the PBL model had been more effective in terms of improving the students' characters than the expo-sitory learning model. The univariate test should meet the assumption that the variance of each variable should be equal. The variance equality might be identified by means of Leven's test and the results of this test provided in Table 4.

Table 4. Levene's Test of Equality of Error Variance

\begin{tabular}{lrrrc}
\hline & F & df1 & df2 & Sig. \\
\hline HOTS & .856 & 1 & 646 & .355 \\
Character & 3.131 & 1 & 646 & .077 \\
\hline
\end{tabular}

Thereby, the researcher might conclude that the variance of each variable had been homogenous. The results of univariate analysis by means of independent sample t-test provided in Table 5.

Based on the results displayed in Table 5, it was apparent that the significance value of HOTS variable that had been attained had been equal to 0.00 . In the significance rate $\alpha=5 \%$, the researcher might conclude that the PBL had been more effective in terms of increasing the students' HOTS than the expository learning. For the characters variable, the significance value had been equal to 0.337 . At the significance level $\alpha=5 \%$, the researcher might conclude that the PBL had not been more effective in terms of improving the students' characters than the expository learning.
Questionnaire Data Analysis: The Identification of Obstacles and the Strategies of PBL

Implementation

In addition to gathering the qualitative data, the researcher also gathered the quantitative data through the open questionnaire. The open questionnaire was completed by the teachers and the objective of distributing this open questionnaire was to identify their responses after implementing the learning process by using the problem-based learning sets and to identify the obstacles that they encountered in implementing the problem-based learning sets. The results of the questionnaire data analysis would be elaborated in the following sections.

The first aspect that the researcher asked was related to the teachers' previous experience in implementing the problem-based learning and the expository learning in order to improve the students' HOTS. The findings that the researcher attained showed that the teachers had still been lack of implementing the problembased learning. The teachers were more comfortable when the learning process was started by explaining the concept directly along with the provision of test item example and of students' exercise. The teachers perceived that such process had been more effective in terms of time allocation and of completing the learning materials. Furthermore, the teachers had not focused the learning process toward the students' higher order thinking skills. Most of the teachers only focused on completing the learning materials in accordance to the curriculum demands. The exercises that the teachers provided were lack of problem-solving activities and the reason that lied behind the provision of such exercises was that the students took longer in completing such exercises since they had not been accustomed to them.

Table 5. Independent Sample t-test Result

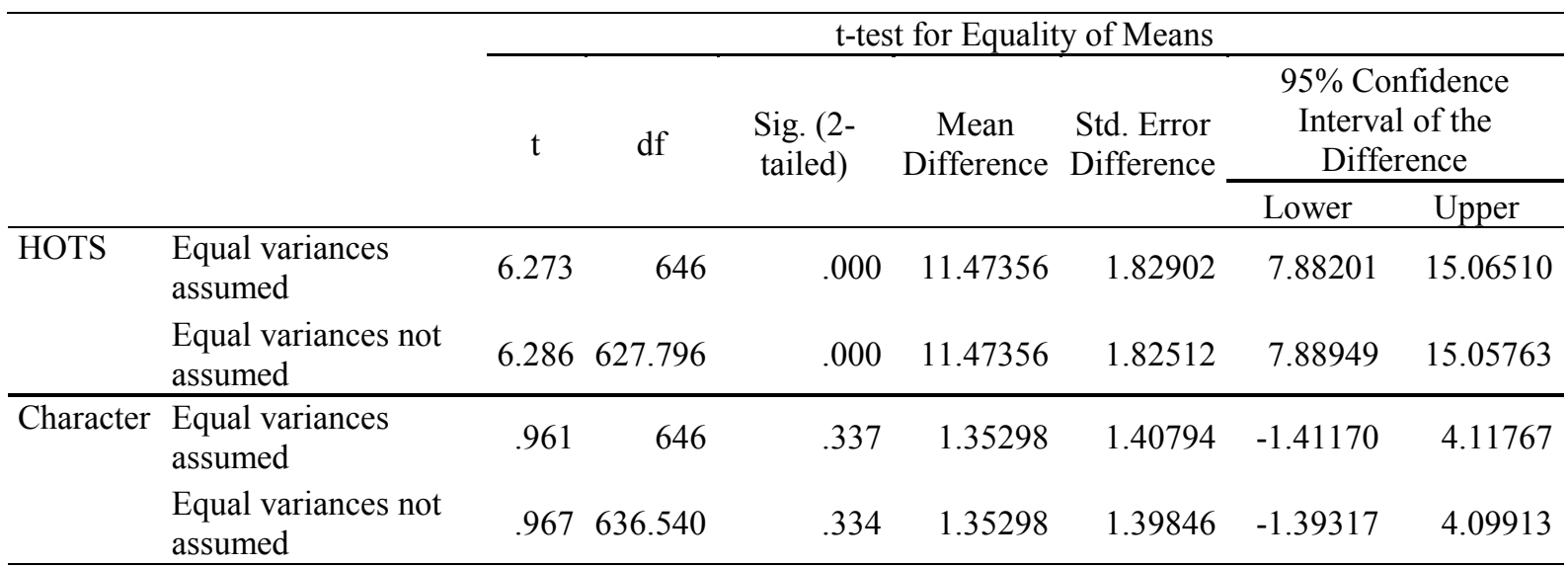




\title{
Jurnal Riset Pendidikan Matematika, 4 (2), 2017 - 253
}

\author{
J. Jailani, S. Sugiman, Ezi Apino
}

In relation to implementing the problembased learning sets, the researcher found several obstacles that the teachers encountered in implementing the problem-based learning and these obstacles came from the teachers' preparedness, the learning implementation, the students and the assessment conduct. In terms of teachers' preparedness, the main obstacles that the teachers encountered were the difficulties in providing the problems that would be suitable to the materials that they should teach and the difficulties in preparing the learning sets such as students' exercise worksheet, and the difficulties in preparing the relevant learning materials. Then, in terms of learning implementation the main obstacle that the teachers encountered was the time allocation. Many teachers complained that the problem-based learning demanded great time allocation; as a result, the time that had been allotted seemed to be insufficient and the learning process could not be conducted as expected. Next, in terms of students the unequal students' input also became another obstacle that the teachers encountered. The students whose academic performance had been low seemed to be less interested into the learning process and these students were inclined to be passive. Another problem that had been related to the students was the students had not been accustomed to completing the problem-based test items and the students had low prerequisite academic capacity. These situations caused the learning process to be slow since most of the learning activities had been focused on guiding the students to solve the problems. Last but not the least, in terms of assessment conduct the obstacles that the teachers encountered were the difficulties in designing the problem-based test items and the assessment rubric. Another obstacle that the teachers also encountered was the very limited time in planning and preparing the teaching-learning process due to the heavy teaching load and the other administrative activities.

Similar to the implementation of problembased learning process, in order to improve the HOTS, the teachers also had multiple obstacles. The main obstacle that the teachers should deal with was that the teachers still had difficulties in designing the HOTS-based test items. The reason was that the teachers had been lack of sources or textbooks that contained the HOTSbased test items. Furthermore, the teachers' being unaccustomed to performing the PBL in order to improve the students' HOTS also influenced the teachers' capacity in designing the HOTS-based test items. The students themselves took quite longer time in completing the HOTS-based test items, which had been another obstacle for the teachers. The reason that lied behind such situation was that the students had not been accustomed to completing the HOTS-based test items. In relation to the assessment conduct, the teachers had difficulties in designing the test sets that contained the HOTS-based test items along with their scoring rubric.

In order to deal with these obstacles, the teachers implemented several strategies. One of the strategies that they implemented was, namely, administering the test items that had been made available by the students' books; certainly, these test items should meet the criteria of the HOTS-based test items. In addition, the teachers also tried to develop the existing test items by changing the number and the context and by expanding the test items through their association with the other context. The teachers also tried to find the other form of problems from any sources, both the printed ones and the online ones. Another strategy that the teachers implemented was maximizing the students' role in the group learning activities. The division group members was conducted in heterogeneous manner: each learning group should have the students with high, moderate and low academic performance and each learning group would be provided with extra assignments both individually and collectively; these tasks would be discussed in order to provide feedback for the students. In relation to the efforts that the teachers pursued in order to improve the students' HOTS, most of the teachers administered the challenging test items that had been sourced from textbooks, administered the Olympic test items that had been related to the materials that the students were learning, adopted the PISA and the TIMSS test items and looked for other references or developed the existing test items. In addition, the teachers also designed the tiered test items from the lower level until the higher level.

The advantage that the teachers perceived in implementing the problem-based learning was that the problem-based learning might train the students to complete the problem-solving type test items so that their HOTS would improve. By implementing the problem-based learning, the students would be more prepared in attending the National Examination. The 
problem-based learning might also improve the students' cooperation and responsibility, which had been facilitated through the group discussions. In addition, the irrelevant activities during the learning process might be suppressed. Through the problem-based learning, the teachers might implement the constructive learning concept in which the students were guided to find the concepts or the formulas that had been related to the materials that they were studying. This situation caused the learning process to be more interesting and meaningful for the students.

About the findings in relation to improving the students' characters, the teachers agreed that the students' characters might be improved through the problem-based learning. The most prominent matter was that the learning process that had been implemented collectively might improve the students' cooperation, responsibility, tolerance and care. On the other hand, in relation to the students' efforts in solving the problems and completing the HOTS-based items, the problem-based learning might shape the characters of persistence, hard-work and selfconfidence. The provision of challenging problems might trigger the students' desire to keep trying to find the solutions from the related problems. The strong desire showed the students' character of persistence and hardwork. For the students who had been able to solve the problems and to complete the HOTSbased test items, they might improve their selfconfidence.

\section{Discussions}

Based on the results of quantitative data analysis, the researcher found that PBL implementation had been more effective in terms of improving the students' HOTS than the expository learning implementation. There were several reasons that supported the statement. First, the PBL activities had been able to develop the students' HOTS (Guedri, 2001; Arends \& Kilcher, 2010; Setiawan, Sugianto \& Djunaedi, 2012). Within the PBL implementation, each of the learning syntaxes was designed in order to facilitate the students' HOTS development. In the first phase, the PBL oriented the students toward the problems; then, the students would perform problem analysis in order to understand the given problems. In this situation, the students were trained to understand the information that they retrieved from the problems and to formulate the hypotheses that they would test based on the problems. These activities would train the students' analysis capacity. Through these activities, the students' capacity in understanding the problem would be trained (Sungur \& Tekkaya, 2006; C. E. HmeloSilver, 2004).

Second, in the third phase of PBL implementation there were the activities of guiding the students into performing investigation individually and collectively; in this phase, the students analyzed and evaluated the problemsolving strategies that they would use and decided which information that would be relevant to the problem-solving process. In these activities, there were three skills that would be developed namely investigating, analyzing and evaluating. Thereby, the activities within the third phase of PBL implementation might sharpen the students' critical thinking capacity (Sungur \& Tekkaya, 2006; C.E. Hmelo-Silver, 2004) which had been the part of HOTS.

Third, the PBL improved the students' indepth understanding and capacity in applying the concept (Wirkala \& Kuhn, 2011). In the fourth phase of PBL implementation, namely developing and solving problems, the students developed their analytical capacity and created ideas that they might implement within the problem-solving process. The students should develop the strategies that they had selected in order to solve the problems by associating the ideas to the other knowledge or discipline. Within the problem-solving process, the students made use of all capacities and skills that they possessed in relation to the problem contexts, including the ones in the students' problem-solving capacities (Loyens, Magda \& Rikers, 2008; Hung, 2009). This would influence the improvement of students' capacity in understanding, planning strategies and solving the problems that had been given. The improvement of those capacities would also contribute to the students' HOTS improvement.

Fourth, in the final phase of PBL implementation, namely analyzing and evaluating the problem-solving process, the students should analyze the problem-solving steps that had been presented and should evaluate the suitability between the steps and the results of the problem-solving process that had been conducted. In this phase, the students held a question-and-answer session in order to test the strength and the weakness of the solution that they had created. These activities might train the students to propose their opinions, 
ideas and thoughts that would be relevant to the topics that they were studying. Such process certainly contributed to the students' critical and creative thinking capacity development. Thereby, through the PBL activities the students' analysis and evaluation capacity might be trained (Weissinger, 2004).

Fifth, in addition to the fact that the syntax in the PBL had been designed to activate the students' capacity through the activities that might develop their HOTS, problems that had been used within the learning process was also important. The problems that became the main key of learning activities were the ill-structure one, which involved multiple knowledge and which might direct the students to perform multiple discovery and investigation activities (Barrows \& Tamblyn in Savin-Bader \& Major, 2004). By involving multiple knowledge/ disciplines of science, the students might train their analysis and evaluation capacity in order to decide which discipline of science or which knowledge that might be relevant to the problems that they would solve. Furthermore, the investigation activities that started from exploring, defining the focus of the problem, developing the solution for the problem until performing evaluation and reflection toward the understanding that had been attained, had been able to direct the students to re-access the knowledge that they had attained so that their understanding would improve, would be more meaningful and would be easier to be applied in other problems/conditions (Wirkala \& Kuhn, 2011). Thereby, the problem characteristics in the PBL became one of the decisive factors in improving the students' HOTS.

Different results were attained from the analysis of the data that had been related to the PBL effectiveness in improving the students' characters. The results of this data analysis showed that the PBL had not been more effective than the expository learning in terms of improving the students' characters. Based on the qualitative data that had also been gathered in the study, there were several factors that became the main cause of such finding. One of these factors was that the students had not been accustomed to the PBL or, in other words, the PBL had been considered relatively new by the students.

The students' being unaccustomed to the PBL influenced the students' unaccustomed to the collaboration activities which had been one the PBL characteristics. This matter of course heavily influenced the implementation of the learning process. The activities that should be conducted in groups became less effective and the activities of group discussion did not run as expected. The discussion process that had not been maximal could not train the students' characters that became the learning orientation, such as: responsibility, care and cooperation. Ideally, within the group collaboration there should be task division for each group member and this task division was expected to train the students' care and responsibility. Through the task division, the students with high academic performance were expected to guide the students with moderate and low academic performance. Unfortunately, in the practice the students had some difficulties in deciding the task division. The guidance by the students with high academic performance itself had not been maximally performed; as a result, the cooperation among the group members had not been manifested. Such situation certainly influenced the establishment of students' characters during the learning process.

Another matter that indicated the ineffectiveness of the group activities within the PBL implementation was the abundant intervention that the teachers performed during the learning activities. The group discussion activities that ran less effectively caused the teachers to provide multiple directions toward each group in order that these groups might discuss the matters that were related to the problems that they should solve. This situation also heavily influenced the students' independence. Eventually, the students might not be trained maximally. Similar situation was also found by Sungur \& Tekkaya (2006) in their study; they found that the PBL had been ineffective in improving the students' independence.

Another impact from the abundant teachers' intervention during the learning process was the lack of efforts and cooperation among the group members in completing the set of activities that the students should perform during the learning process. One of the example from this situation would be the analysis and the problem-solving process. Here, the students became dependable on the directions that the teachers provided; as a consequence, the students became easily desperate when they had confusion or difficulties in completing their assignments. This dependency became an indication that the students' persistence and 
hard-work had not been established during the learning process. Furthermore, when they were asked to present the results of their group discussion the students were not confident with themselves. The students would present their discussion results after they had been appointed directly by the teachers. This matter indicated that the students' self-confidence character had not been established well.

Tan (2004) stated that one of the capacities that had been trained in the PBL had been the problem-solving capacity. The less effective learning activities was perceived to pay quite enormous contribution to the students' problem-solving capacity. In the practice, during the learning process most of the students considered that the problems that been given were too difficult and they were less motivated to solve them. For the students who had been able to solve the given problems, their confidence certainly would be improved. On the contrary, for the students who had been unable to solve or who had even failed in solving the problems their self-confidence would be decreased. Thereby, the students' being unaccustomed to the PBL resulted in the low students' problem-solving capacity and indirectly influenced the students' self-confidence.

The teachers encountered several obstacles when they implemented the PBL into the learning activities. They sensed that the time that had been allocated to the learning activities had been low. The reason was that the discussion had been slow since the teachers should perform multiple interventions during the learning activities. In addition, the students' low problem-solving capacity became another contributor to such situation. According to the teachers, the learning process that made use of lecture and that would proceed to example and exercise provision would be more effective for the students in terms of time allocation within the learning activities.

Based on the results of the study, the researcher found that up to date the teachers had not oriented classroom learning process to the students' HOTS. The learning process that had been carried out in the classroom was still oriented the learning material accomplishment in accordance to the 2013 Curriculum. This finding was also caused by the teachers' difficulties in preparing the problems, the students' exercise worksheets or the other learning materials that would be implemented in the learning activities. The similar obstacles that had been related to the time allocation and the teachers' preparedness was also found by Bouhuijs (2011) in his study. Another matter that the teachers perceived to the factor of less effective learning process by means of PBL implementation was the unequal students' input. The students with low academic performance seemed uninterested with the learning activities during the learning process; as a result, they became passive during the learning activities. Similar matter was also found by Chan (2012) in his study regarding the PBL implementation in the classroom.

In relation to multiple obstacles that the researcher found in the PBL implementation within the classroom, several strategies might be implemented by the teachers during the learning process. In order to deal with the ineffectiveness of collaboration in the group, the teachers divided the students into several groups by paying attention to the heterogeneity and the number of the members; there would not be too many members in a group. A study y C.E. Hmelo-Silver (2004) showed that the small group would be more effective within the process of knowledge construction and of group discussions.

\section{CONCLUSIONS AND SUGGESTIONS}

Based on the results of the study and the discussions, the researcher would like to conclude that the PBL implementation has been more effective than the expository learning implementation in terms of improving the students' HOTS; however, the PBL implementation has not been more effective than the expository learning in terms of improving the students' characters. Several factors that contribute to the consideration that PBL has been effective in terms of improving the students' HOTS are namely: (1) each phase in the PBL turns the students to be more active in performing the activities of analyzing, evaluating and creating ideas through the problemsolving activities; and (2) the characteristics of the problems that have been implemented activate the students in the discovery and investigation analysis. The factors that have been suspected to became the main cause in the consideration that the PBL has not been effective in improving the students' characters is that the students' being unaccustomed to attend the problem-based learning process. This factor has caused several matters namely: (1) the activities of group collaboration have not been 
implemented effectively so that the students' characters, namely responsibility, care and cooperation have been less trained; (2) there have been abundant teachers' interventions within the learning process so that the students' characters, namely independence, persistence and hard-work have not been trained maximally; and (3) the low students' problem-solving capacity has resulted in their lack of self-confidence.

There are several obstacles that the teachers encounter within the PBL implementation that aims to improve both the students' HOTS and the students' characters. First, in relation to the teachers' preparedness, the teachers still have difficulties in providing the problems that are relevant to the materials that the students will learn, difficulies in creating the HOTSbased test items and difficulties in providing the learning sets. Second, in relation to the learning implementation, the teachers have difficulties in performing the time allocation management. Third, in terms of students' input, the unequal students' input and the students' being unaccustomed to the problem-based learning have caused the learning activities such as discussions and presentations to be less effective. Fourth, in relation to the assessment conduct, the teachers still have difficulties in designing the HOTS test instrument and its scoring rubric.

Based on the findings in the study and the conclusions, the researcher would like to recommend teachers that they should implement the problem-based learning as one of the methods or the models that might be applied in the learning process in order to improve the students' HOTS. In addition, the teachers should attend multiple training programs that are related to developing the HOTS-based test items or should expand the references that they read in looking for or in designing problems that are related to the students' HOTS. For the policymakers, the researcher would like to recommend that the policymakers should provide training programs for the teachers in relation to the problem-based learning and the development of students' HOTS, regarding the fact that this learning model is one of the models that have been suggested by the 2013 Curriculum. For the future studies, the researcher would like to recommend that there should be similar studies in the future that gathered more various sample in terms of students' capacity, of regional characteristics and of other factors so that the future researchers might attain real description in relation to the main obstacles within the PBL implementation and the strategies that might be taken in order to overcome those strategies based on the empirical experience in the field.

\section{REFERENCES}

Anderson, O. W., \& Krathwohl, D. R. (2001). Taxonomy of learning, teaching and assessing. New York, NY: Longman.

Araz, G., \& Sungur, S. (2007). Problem based learning effectiveness of problem based learning on academic performance in genetics. The Interational Union of Biochemistry and Molecular Biology, 6(35), 448-451.

Arends, R. I. (2012). Learning to teach ( $9^{\text {th }}$ ed.). New York, NY: McGraw-Hill Companies, Inc.

Arends, R. I., \& Kilcher, A. (2010). Teaching for students learning:Becoming an accomplished teacher. New York, NY: Taylor \& Francis.

Bidokht, M. H., \& Assareh, A. (2011). Life-long learners through problem-based and self directed learning.Procedia Computer Science, 3(1), 1446-1453. https://doi.org/10.1016/j.procs.2011.01.02 8

Bouhuijs, P. A. J. (2011). Implementing problem based learning: Why is it so hard?. Revista de Docencia Universitaria, 9(1), 17-24 .

Brookhart, S. M. (2010). How to assess higherorder thinking skills in your classroom. Alexandria, VA: ASCD.

Chan, Z. C. Y. (2012). Role-playing in the problem-based learning class. Nurse Education in Practice, 12(1), 21-27. https://doi.org/10.1016/j.nepr.2011.04.008

Conklin, W. (2012). Higher order thinking skills to develop $21^{\text {th }}$ century learners. Huntington, CA: Shell Education Publishing.

Creswell, J. W. (2013). Qualitative inquiry and research design: Choosing among five approaches ( $2^{\text {nd }}$ ed.). Thousand Oaks, CA: Sage Publication, Inc.

Douglas, E. P. (2012). Defining and measuring critical thinking in engineering. Procedia - Social and Behavioral Sciences, 56 (1), 153-159. https://doi.org/10.1016/j.sbspro.2012.09.6 42 


\section{Jurnal Riset Pendidikan Matematika, 4 (2), 2017 - 258}

J. Jailani, S. Sugiman, Ezi Apino

English, M. C., \& Kitsantas, A. (2013). Supporting student self-regulated learning in problem- and project-based learning. Interdisciplinary Journal of E-Learning and Learning Objects, 7(2), 128-150. https://doi.org/http://dx.doi.org/10.7771/1 541-5015.1339

Fitrianawati, M., \& Hartono, H. (2016). Perbandingan keefektifan PBL bersetting TGT dan GI ditinjau dari prestasi belajar, kemampuan berpikir kreatif dan toleransi. Jurnal Riset Pendidikan Matematika, 1(3), 55-65.

Guedri, P. Z. (2001). Problem-based learning: Bringing higher order thinking to business schools. Cahier de Recherche OIPG, 1(2), 1-17.

Hmelo-Silver, C. E. (2004). Problem-based learning: What and how do students learn. Educational Psychology Review, 16(3), 235-266.

https://doi.org/10.1023/B:EDPR.0000034 022.16470.f3

Hung, W. (2009). The 9-step problem design process for problem-based learning: Application of the 3C3R model. Educational Research Review, 4(2), 118141.

https://doi.org/10.1016/j.edurev.2008.12.0 01

Johnson, R. A., \& Winchern, D. W. (2007). Applied multivariate statistical analysis $\left(6^{\text {th }}\right.$ ed.). Upper Saddle River, NJ: Pearson Eduucation

King, F. J., Goodson, L., \& Rohani, F. (2010). Higher order thinking skills: Deffinition, teaching strategies, assessment. New York, NY: Educatiional service program.

King, F. J., Goodson, L., Rohani, F., Level, D. K., Plan, Q. E., Oliver, S., ... Order, H. (2015). Improving students' higher-order thinking competencies, including critical evaluation, creative thinking, and reflection on their own thinking. Research in Science Education, 3(2), 1-41. https://doi.org/10.1007/s11165-006-90292

Lickona, T. (1991). Educating for character how our school can teach respect and responsibility. New York. Bantam Books

Loyens, S. M. M., Magda, J., \& Rikers, R. M. J. P. (2008). Self-directed learning in problem-based learning and its relationships with self-regulated learning. Educational Psychology Review, 20(4), 411-427. https://doi.org/10.1007/s10648008-9082-7

Marsigit. (Juni 2013). Tantangan dan harapan Kurikulum 2013 bagi pendidikan matematika. Makalah dipresentasikan pada Seminar Nasional Matematika dan Pendidikan Matematika Universitas PGRI Yogyakarta, di Universitas PGRI Yogyakarta.

Mendikbud. (2016a). Peraturan Menteri Pendidikan dan Kebudayaan Nomor 20 Tahun 2016 tentang Standar Kompetensi Lulusan Pendidikan Dasar dan Menengah.

Mendikbud. (2016b). Peraturan Menteri Pendidikan dan Kebudayaan Nomor 21 Tahun 2016 tentang standar isi pendidikan dasar dan menengah.

Mei Heong, Y., Md Yunos, J., Othman, W., Hassan, R., Tze Kiong, T., \& Mohaffyza Mohamad, M. (2012). The needs analysis of learning higher order thinking skills for generating ideas. Procedia -Social and Behavioral Sciences, 59, 197-203. https://doi.org/10.1016/j.sbspro.2012.09.2 65

Moore, B., \& Stanley, T. (2010). Critical thinking and formative assessment. Larchmont, NY: Eye on Education.

Moss, C. N., \& Brookhart, S. M. (2009). Advancing formatif assessment in every classroom. Alexandria, VA: ASCD.

Mullis, I. V. S., Martin, M. O., Gonzalez, E. J., Gregory, K. D., Garden, R. A., O'Connor, K. M., Crotowski, S. J., \& Smith, T. A. (2000). TIMSS 1999 international mathematics report: Finding from IEA's trends in international mathematics and science study at the fourth and eighth grades. Chestnut hill, MA: International Study Center Lynch School of Education Boston College.

Mullis, I., et al. (2004). TIMSS 1999 international mathematics report. Chestnut hill, MA: International Study Center Lynch School of Education Boston College.

Mullis, I. V. S., Martin, M. O., Foy, P., \& Arora, A. (2012). TIMSS 2011 international results in mathematics. Chestnut Hill, MA: IEA 
Partnership for 21st Century Skills (P21). (2015). Framework for $21^{\text {st }}$ century learning. diakses dari https://goo.gl/Knkilz.

Ramos, J. L., Dolipas, B. B., \& Villamor, B. B. (2013). Higher order yhinking skills and academic performance in physics of college students: A regression analysis. International Journal of Innovative Interdisciplinary Research, IV(1), 46-80.

Richland, L. E., \& Simms, N. (2015). Analogy, higher order thinking, and education. WIREs Cognitive Science 2015, 1-16. https://doi.org/10.1002/wcs. 1336

Savin-Baden, M., \& Major, C. H. (2004). Foundation of problem based learning. New York, NY: Open Univerity Press.

Setiawan T., Sugiarto, \& Junaedi. (2012). Pengembangan perangkat pembelajaran matematika dengan pendekatan problembased learning untuk meningkatkan keterampilan higher order thinking. Unnes Journal of Research Mathematics Education, 1(1), 72-80.

Sungur, S., \& Tekkaya, C. (2006). Effects of problem-based learning and traditional instruction on self-regulated learning. The Journal of Educational Research, 99(5), 307-320. https://doi.org/10.3200/JOER.99.5.307-320

Sumarmo, U., \& Nishitani, I. (2010). High level mathematical thinking: Experiments with high school and under graduate students using various approach and strategies. Diunduh pada 26 Februari 20016 dari https://goo.gl/5illwi.

Susanti E, Kusumah Y S, Sabandar, J., \& Darhim. (2014). Computer-assisted realistic mathematics education for enhancing students' higher-order thinking skills (experimental study in junior high school in Palembang, Indonesia). Journal of Education and Practice, 5(18), 51-58.

Tan, O. S., (2004). Enhancing thinking through problem based learning approaches. Singapore: Cengange Learning.

Tan, S. Y., \& Halili, S. H. (2015). Effective teaching of higher-order thinking (HOT) in education. The Online Journal of Distance Education and E-Learning, 3(2), 41-47.

Weissinger, P. A. (2004). Critical thinking, metagocnition, and problem based learning. Dalam O. S. Tan (Eds.), Enhancing Thinking through Problem Based Learning Approach.Singapore: Cengange Learning.

Wirkala, C., \& Kuhn, D. (2011). Problem-based learning in K-12 education: Is it effective and how does it achieve its effects? American Educational Research Journal, 48(5), 1157-1186. https://doi.org/10.3102/0002831211419491. 